\title{
GENE-EXPRESSION ANALYSIS REVEALS THAT EMBRYONIC STEM CELLS CULTURED UNDER OSTEOGENIC CONDITIONS PRODUCE MINERAL NON- SPECIFICALLY COMPARED TO MARROW STROMAL CELLS OR OSTEOBLASTS
}

\author{
Nicholas D. Evans ${ }^{1,2, \dagger}$, Robin J. Swain ${ }^{1,2}$, Eileen Gentleman ${ }^{1,2, \$}$, Molly M. Gentleman $^{3}$ and Molly M. Stevens ${ }^{1,2 *}$
}

${ }^{1}$ Department of Materials and ${ }^{2}$ Institute of Biomedical Engineering, Imperial College London, London, UK ${ }^{3}$ Mechanical Engineering Department, Texas A\&M University, College Station, TX, USA

\author{
${ }^{\dagger}$ Present affiliation: Institute of Developmental Sciences, University of Southampton School of Medicine, Southampton, UK \\ † Present affiliation: Craniofacial Development \& Stem Cell Biology, King’s College London, London, UK
}

\begin{abstract}
Pluripotent cells, such as embryonic stem cells (ESCs), divide indefinitely and can differentiate to form mineralised nodules in response to osteogenic supplements. This suggests that they may be used as a cell source for bone replacement strategies. Here, we related the expression of osteogenic and chondrogenic genes in cultures of murine ESCs, marrow stromal cells (MSCs) and calvarial osteoblasts (OBs) cultured under osteogenic conditions to the biochemical composition and quantity of mineral formed. Mineralisation, measured by calcium sequestration, was >2-fold greater in ESC cultures than in either MSCs or OBs. Micro-Raman spectroscopy and spectral mapping revealed a lower mineral-to-matrix ratio and confirmed a more diffuse pattern of mineralisation in ESCs compared to MSCs and OBs. Baseline expression of chondrogenic and osteogenic genes was between 1 and 4 orders of magnitude greater in MSCs and OBs than in ESCs. Osteogenic culture of MSCs and OBs was accompanied by increases in osteogenic gene expression by factors of $\sim 100$ compared to only 10 in ESCs. Consequentially, peak expression of osteogenic and chondrogenic genes was greater in MSCs and OBs than ESCs by factors of 100-1000, despite the fact that mineralisation was more extensive in ESCs than either MSCs or OBs. We also observed significant cell death in ESC nodules. We conclude that the mineralised material observed in cultures of murine ESCs during osteogenic differentiation may accumulate non-specifically, perhaps in necrotic cell layers, and that thorough characterisation of the tissue formed by ESCs must be achieved before these cells can be considered as a cell source for clinical applications.
\end{abstract}

Keywords: Bone; development; mineralisation; repair; stem cells; differentiation; osteogenesis.

*Address for correspondence:

Molly M. Stevens

Department of Materials

Institute of Biomedical Engineering

Imperial College London

South Kensington, London SW7 2AZ, UK

Telephone Number: +44 (0)20 75946804

FAX Number: +44 (0)20 75946757

Email:m.stevens@imperial.ac.uk
Bone or joint injury and disease often result in such a severe loss of tissue that restoration of function can only be achieved by its replacement with either transplanted material or a biomaterial prosthesis. The implanted material should provide an environment containing appropriate mechanical and molecular signals conducive to bone formation through the action of endogenous or implanted cells (Giannoudis et al., 2007). Autografting is the preferred, 'gold standard' treatment for bone injuries, but the amount of tissue that can be harvested may be limited, and pain and morbidity may result at the donor site (Arrington et al., 1996), problems that are compounded in elderly patients (Giannoudis et al., 2005). Allografts may also be used, but these cadaveric tissues may be of poor quality and have the inherent risk of patient-to-patient disease transmission (Kainer et al., 2004). Many artificial or sterilised tissue-derived biomaterials, often based on recombinant bone morphogenic proteins (BMPs) are used as alternatives to allografts (Place et al., 2009), but these are generally inferior in their ability to promote tissue regeneration, or in some cases may induce aberrant healing and heterotopic bone (Boraiah et al., 2009). To circumvent some of these problems, cells - expanded in vitro and implanted possibly in combination with a physical scaffold - are being considered as an alternative therapy.

There are several candidates as cell sources for bone 'tissue engineering'. Marrow stromal cells (MSC), discovered in the 1960s (Friedenstein et al., 1970), have a high proliferative potential and contribute to healing bone in animal models (Bruder et al., 1998). It is considered that stem cells, resident in these mixed cell populations, are responsible for both the extended proliferation and multilineage capacity of these cultures. But MSCs do not divide indefinitely. This may limit their use in bone tissue engineering, where large, voluminous constructs may be required to achieve repair. Pluripotent cells, on the other hand, including embryonic stem cells (ESCs) (Evans and Kaufman, 1981; Thomson et al., 1998) and induced pluripotent stem cells (iPSCs) (Takahashi and Yamanaka, 2006), have the ability to both divide indefinitely and differentiate into all cell types found in the adult organism. Embryonic stem cells are less committed than either adult stem cell populations or tissue-specific cells. During differentiation to a given lineage, it is likely that ESCs must pass through more stages of differentiation and make more cell fate decisions than adult stem cells. For instance, ESCs must first commit to a germ layer before turning into a progenitor cell type of the tissue in question. 
In contrast, it is assumed that MSCs or osteoblasts are already primed to differentiate into connective tissue cells or terminally differentiated cells, respectively. Despite this, several studies have reported osteogenic differentiation of ESCs when cultured with supplements commonly used to induce mineralised nodule formation in primary osteoblast (OB) cultures (Bielby et al., 2004; Buttery et al., 2001; Kawaguchi et al., 2005; Phillips et al., 2001; zur Nieden et al., 2005). However, we recently noted marked differences in the composition of the mineral and the ultrastructure of the nodules formed from ESCs compared to those formed from either MSCs or OBs (Gentleman et al., 2009). This indicates that different mechanisms of differentiation and mineralisation may operate in ESCs compared to the latter cell types.

Here, to better characterise the pattern of differentiation in ESCs compared to MSCs or OBs, we expand upon our previous study by directly comparing gene transcription during osteogenic culture in the three cell types, and by assessing the morphology and mineral content of nodules. To achieve this, we employed a combination of histological staining and biochemical assay techniques with micro-Raman spectroscopy and quantitative polymerase chain reaction (qPCR). Since it is now established that experimental conditions, cell type or differentiation state (Vandesompele et al., 2002) can affect the expression of 'housekeeping' genes (used as normalisers in qPCR for genes of interest), we first evaluated the expression of three potential housekeeping genes in order to establish the most suitable reference gene for comparisons between cell types and experimental conditions. We then tested the hypothesis that, while there are similarities in the material composition of the mineralised tissue that these cells form, the molecular mechanism by which differentiation occurs differs markedly between them.

\section{Materials and Methods}

\section{Ethics statement}

Animals were sacrificed humanely under Schedule 1 of the Animal Procedures Committee of the United Kingdom Home Office. These procedures do not require specific approval in the UK, but were conducted in accordance with Imperial College's ethics guidelines under licence PCD 70/2707.

\section{Cell isolation and culture}

E14 TG2 $\alpha$ ESCs were cultured on gelatin-coated surfaces $(0.1 \%(\mathrm{w} / \mathrm{v})$ in phosphate buffered saline [PBS] for $24 \mathrm{~h}$ prior to culture) in DMEM supplemented with $10 \%$ (v/v) fetal bovine serum (FBS), $2 \mathrm{mM}$ L-glutamine, $50 \mathrm{U} / \mathrm{mL}$ penicillin, $50 \mathrm{mg} / \mathrm{mL}$ streptomycin (Invitrogen, Paisley, UK), $100 \mu \mathrm{M} \beta$-mercaptoethanol (Sigma, Poole, $\mathrm{UK}$ ), and $1000 \mathrm{U} / \mathrm{mL}$ leukaemia inhibitory factor (LIF) (Chemicon, Chandler's Ford, UK). Cells were seeded at $6000-8000$ cells $/ \mathrm{cm}^{2}$ and passaged every 3-4 d. MSCs were isolated from the femora of female $\mathrm{FVB} / \mathrm{N}$ mice by removing the epiphyses and passing growth medium ( $\alpha$ MEM supplemented with $15 \%$ (v/v) FBS, $50 \mathrm{U} / \mathrm{mL}$ penicillin, and $50 \mathrm{mg} / \mathrm{mL}$ streptomycin) several times through the marrow cavity of the diaphyses. Marrow cells were collected in tissue culture flasks and allowed to attach for $9 \mathrm{~d}$. Adherent cells were then passaged at $90 \%$ confluence and fed every 2-3 d with growth medium before use in differentiation experiments. OBs were isolated from the calvaria of neonate CD-1 mice. Soft tissue was removed from the bone and the bone was then rinsed in $500 \mathrm{U} / \mathrm{mL}$ penicillin and $500 \mathrm{mg} / \mathrm{mL}$ streptomycin in PBS for $5 \mathrm{~min}$. Calvaria were then transferred to a solution containing $0.05 \%(\mathrm{w} / \mathrm{v})$ trypsin and $0.1 \%(\mathrm{w} / \mathrm{v})$ collagenase $\mathrm{P}$ and were minced finely with dissecting scissors. Bone fragments were subjected to five $15 \mathrm{~min}$ digestions; at the end of each digestion the supernatant was removed, centrifuged, and cells were resuspended in growth medium and plated in a $25 \mathrm{~cm}^{2}$ flask, while fresh trypsin-collagenase solution was added to the fragments. Cells from digestions III, IV and V were pooled, passaged at confluence and fed every 2-3 d with growth medium before use in differentiation experiments. MSCs and OBs were used at passage 1 or 2 in all experiments, and experiments described were conducted on cells obtained from 3 separate cell isolations (for both MSCs and OBs). FBS in all experiments was batch-tested for its ability to support bone nodule formation in differentiating cultures of MC3T3-E1 osteoblasts (FBS reserve number 1222532, batch 07F7260K, Invitrogen).

\section{Differentiation of cells}

To induce embryoid body (EB) formation, ESCs were dissociated into clumps of around 20 cells by partial trypsin digestion and transferred to bacteriological-grade $90 \mathrm{~mm}$ Petri dishes. EBs were cultured in suspension for $5 \mathrm{~d}$ in aMEM supplemented with $15 \%$ (v/v) FBS, $50 \mathrm{U} / \mathrm{mL}$ penicillin and $50 \mathrm{mg} / \mathrm{mL}$ streptomycin with feeding after $3 \mathrm{~d}$. After $5 \mathrm{~d}$ (referred to in differentiation experiments as day 0) EBs were dissociated into single cells with trypsinEDTA (Invitrogen) and seeded at a density of 30,000 cells/ $\mathrm{cm}^{2}$ in $\alpha$ MEM supplemented with $10 \%$ (v/v) FBS, $50 \mathrm{U} /$ $\mathrm{mL}$ penicillin, $50 \mathrm{mg} / \mathrm{mL}$ streptomycin, $280 \mu \mathrm{M}$ ascorbate, $10 \mathrm{mM} \beta$-glycerophosphate and $1 \mu \mathrm{M}$ dexamethasone (differentiation medium) and were then fed every 2-3 $\mathrm{d}$ for a period of up to $28 \mathrm{~d}$. Both MSCs and OBs were seeded at 30,000 cells $/ \mathrm{cm}^{2}$ in the same medium and cultured for the same period of time.

\section{Alizarin red S staining, mineral quantification and cell death assay}

At day 21, cells cultures were washed twice in PBS and fixed for $20 \mathrm{~min}$ in $10 \%(\mathrm{v} / \mathrm{v})$ formalin buffered saline. Cells were then washed and incubated in $2 \%(\mathrm{w} / \mathrm{v})$ alizarin red S (ARS; Sigma), pH 4.2 for $10 \mathrm{~min}$. Cultures were washed in running tap water for $30 \mathrm{~min}$, and were then left to air dry. Cells were examined under an inverted epifluorescence microscope at wavelengths of 510-560 nm excitation and $>590 \mathrm{~nm}$ emission. Calcium content was quantified as previously described (McCullen et al., 2010). After $21 \mathrm{~d}$ in culture, cultures were washed with PBS and digested in $0.5 \mathrm{M} \mathrm{HCl}$ at $4{ }^{\circ} \mathrm{C}$ overnight. Calcium content was assessed with a Calcium Colorimetric Assay Kit (BioVision Research Products, Mountain View, CA, USA) based on the formation of a chromogenic complex 
Table 1. Sequences and cycling conditions of primers used in $\mathrm{qPCR}$.

\begin{tabular}{|c|c|c|c|c|}
\hline & $\begin{array}{l}\text { Gene } \\
\text { name }\end{array}$ & $\begin{array}{l}\text { GenBank } \\
\text { Accession }\end{array}$ & Primer Sequence & $\begin{array}{l}\text { Cycling } \\
\text { conditions }\end{array}$ \\
\hline \multirow{3}{*}{ 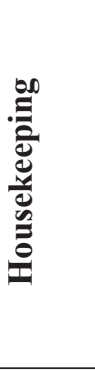 } & Gapdh & NM_008084 & $\begin{array}{l}\text { AGGTCGGTGTGAACGGATTTG } \\
\text { TGTAGACCATGTAGTTGAGGTCA }\end{array}$ & $\begin{array}{l}95^{\circ} \mathrm{C} 10 \mathrm{~s} \\
56^{\circ} \mathrm{C} 15 \mathrm{~s} \\
72^{\circ} \mathrm{C} 15 \mathrm{~s}\end{array}$ \\
\hline & $B 2 m$ & NM_009735 & $\begin{array}{l}\text { TTCTGGTGCTTGTCTCACTGA } \\
\text { CAGTATGTTCGGCTTCCCATTC }\end{array}$ & $\begin{array}{l}95^{\circ} \mathrm{C} 10 \mathrm{~s} \\
58^{\circ} \mathrm{C} 15 \mathrm{~s} \\
72^{\circ} \mathrm{C} 15 \mathrm{~s}\end{array}$ \\
\hline & $A c t b$ & NM_007393 & $\begin{array}{l}\text { GGCTGTATTCCCCTCCATCG } \\
\text { CCAGTTGGTAACAATGCCATGT }\end{array}$ & $\begin{array}{l}95^{\circ} \mathrm{C} 10 \mathrm{~s} \\
58^{\circ} \mathrm{C} 15 \mathrm{~s} \\
72^{\circ} \mathrm{C} 15 \mathrm{~s}\end{array}$ \\
\hline \multirow{2}{*}{ 总 } & Nanog & NM_028016 & $\begin{array}{l}\text { TTGCTTACAAGGGTCTGCTACT } \\
\text { ACTGGTAGAAGAATCAGGGCT }\end{array}$ & $\begin{array}{l}95^{\circ} \mathrm{C} 10 \mathrm{~s} \\
58^{\circ} \mathrm{C} 15 \mathrm{~s} \\
72^{\circ} \mathrm{C} 15 \mathrm{~s}\end{array}$ \\
\hline & Oct4 & NM_013633 & $\begin{array}{l}\text { TTGCTTACAAGGGTCTGCTACT } \\
\text { ACTGGTAGAAGAATCAGGGCT }\end{array}$ & $\begin{array}{l}95^{\circ} \mathrm{C} 10 \mathrm{~s} \\
58^{\circ} \mathrm{C} 15 \mathrm{~s} \\
72^{\circ} \mathrm{C} 15 \mathrm{~s}\end{array}$ \\
\hline \multirow{2}{*}{ 㒸 } & Sox 9 & NM_011448 & $\begin{array}{l}\text { GAGCCGGATCTGAAGAGGGA } \\
\text { GCTTGACGTGTGGCTTGTTC }\end{array}$ & $\begin{array}{l}95^{\circ} \mathrm{C} 10 \mathrm{~s} \\
56^{\circ} \mathrm{C} 15 \mathrm{~s} \\
72^{\circ} \mathrm{C} 15 \mathrm{~s}\end{array}$ \\
\hline & Col2al & NM_031163 & $\begin{array}{l}\text { GGGAATGTCCTCTGCGATGAC } \\
\text { AGCCGCGAAGTTCTTTTCTCC }\end{array}$ & $\begin{array}{l}95^{\circ} \mathrm{C} 10 \mathrm{~s} \\
56^{\circ} \mathrm{C} 15 \mathrm{~s} \\
72^{\circ} \mathrm{C} 15 \mathrm{~s}\end{array}$ \\
\hline \multirow{6}{*}{ 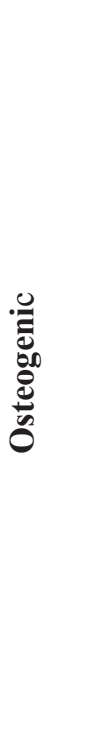 } & Bglap & NM_031368 & $\begin{array}{l}\text { CTGACCTCACAGATCCCAAGC } \\
\text { TGGTCTGATAGCTCGTCACAAG }\end{array}$ & $\begin{array}{l}95^{\circ} \mathrm{C} 10 \mathrm{~s} \\
56^{\circ} \mathrm{C} 15 \mathrm{~s} \\
72^{\circ} \mathrm{C} 15 \mathrm{~s}\end{array}$ \\
\hline & Sparc & NM_009242 & $\begin{array}{l}\text { GTGGAAATGGGAGAATTTGAGGA } \\
\text { CTCACACACCTTGCCATGTTT }\end{array}$ & $\begin{array}{l}95^{\circ} \mathrm{C} 10 \mathrm{~s} \\
56^{\circ} \mathrm{C} 15 \mathrm{~s} \\
72^{\circ} \mathrm{C} 15 \mathrm{~s}\end{array}$ \\
\hline & Akp2 & NM_007431 & $\begin{array}{l}\text { CCAACTCTTTTGTGCCAGAGA } \\
\text { GGCTACATTGGTGTTGAGCTTTT }\end{array}$ & $\begin{array}{l}95^{\circ} \mathrm{C} 10 \mathrm{~s} \\
56^{\circ} \mathrm{C} 15 \mathrm{~s} \\
72^{\circ} \mathrm{C} 15 \mathrm{~s}\end{array}$ \\
\hline & Sppl & NM_009263 & $\begin{array}{l}\text { AGCAAGAAACTCTTCCAAGCAA } \\
\text { GTGAGATTCGTCAGATTCATCCG }\end{array}$ & $\begin{array}{l}95^{\circ} \mathrm{C} 10 \mathrm{~s} \\
56^{\circ} \mathrm{C} 15 \mathrm{~s} \\
72^{\circ} \mathrm{C} 15 \mathrm{~s}\end{array}$ \\
\hline & Runx2 & NM_009820 & $\begin{array}{l}\text { CCAACCGAGTCATTTAAGGCT } \\
\text { GCTCACGTCGCTCATCTTG }\end{array}$ & $\begin{array}{l}95^{\circ} \mathrm{C} 10 \mathrm{~s} \\
56{ }^{\circ} \mathrm{C} 15 \mathrm{~s} \\
72{ }^{\circ} \mathrm{C} 15 \mathrm{~s}\end{array}$ \\
\hline & Collal & NM_007742 & $\begin{array}{l}\text { GCTCCTCTTAGGGGCCACT } \\
\text { CCACGTCTCACCATTGGGG }\end{array}$ & $\begin{array}{l}95^{\circ} \mathrm{C} 10 \mathrm{~s} \\
56^{\circ} \mathrm{C} 15 \mathrm{~s} \\
72^{\circ} \mathrm{C} 15 \mathrm{~s}\end{array}$ \\
\hline
\end{tabular}

between o-cresolphthalein and calcium ions, and quantified by measuring absorbance at $575 \mathrm{~nm}$ on a colorimetric plate reader (Molecular Devices, Wokingham, UK). For determining cell death in cultures of cells, cultures were stained with ethidium homodimer 1 (Invitrogen) at day 21 of culture by incubation with $5 \mu \mathrm{M}$ of the reagent for $30 \mathrm{~min}$ in cell culture medium. Cells were then imaged using inverted epifluorescence microscope at wavelengths of 510-560 nm excitation and $>590 \mathrm{~nm}$ emission.

\section{Raman spectroscopy}

Raman spectra of live cell cultures and bone samples were collected in DMEM at $37{ }^{\circ} \mathrm{C}$ as previously described (Gentleman et al., 2009) with a Renishaw InVia spectrometer connected to a Leica microscope and equipped with a $785 \mathrm{~nm}$ line-focus laser. Spectra were recorded at a resolution of $\sim 1-2 \mathrm{~cm}^{-1}$, with $100 \mathrm{~s}$ integration time. For mineralised nodules, spectra of live cultures were collected along a line through the centre of the nodule at equally-spaced intervals. Some nodules were also rinsed in PBS and dried in a bell jar desiccator prior to Raman spectroscopic analysis to create spectral maps. These spectra were collected using a Renishaw InVia spectrometer with a $532 \mathrm{~nm}$ line-focus doubled Nd:YAG laser connected to a Leica confocal microscope with a motorised stage. An 1800 line/mm grating was used in scanning mode (10 s/scan) to collect spectra (350 to 3200 Raman shift $\mathrm{cm}^{-1}$ ) with $\sim 1 \mathrm{~cm}^{-1}$ resolution. One-second static scans were also completed for each map position with a limited spectral range $\left(900 \mathrm{~cm}^{-1}\right.$ to $\left.1700 \mathrm{~cm}^{-1}\right)$ to confirm that no laser damage was observed during the $10 \mathrm{~s}$ extended scans. For each nodule, spectra were collected in $\sim 40 \mu \mathrm{m}$ x $50 \mu \mathrm{m}$ sections with $1 \mu \mathrm{m}$ raster steps between measurements. Prior to each measurement, the system 
was calibrated for position and intensity using an internal silicon standard. For live cell cultures, Raman spectra were processed and analysed with software developed in-house for use in The Matlab (The Mathworks, Cambridge, UK). Raman spectra were intensity-corrected for instrument response, and the background subtracted using the Modpoly algorithm (5th order polynomial, 1000 iterations) (Lieber and Mahadevan-Jansen, 2003). Individual spectra were lightly smoothed using a 5-point Savitsky-Golay filter (2nd order polynomial) (Savitsky and Golay, 1964), and the wavenumber axis of each spectrum was standardised and aligned to the sharp phenylalanine peak at $1003 \mathrm{~cm}^{-1}$. Prior to analysis, a linear baseline was subtracted from each band envelope. For Raman spectral maps of dried samples, no pre-processing was conducted on the spectra prior to curve fitting. All curve-fitting was completed using Renishaw's Wire software. Phosphate mineral content was estimated by fitting one (for maps) or two bands to the $\mathrm{PO}_{4}^{3-} v_{1}$ stretch at approximately $960 \mathrm{~cm}^{-1}$. To estimate matrix content, two curves were fit to the baseline-corrected 1600-1700 $\mathrm{cm}^{-1}$ spectral region to model the amide I band at $\sim 1650 \mathrm{~cm}^{-1}$ and the $\mathrm{C}=\mathrm{C}$ stretch of amino acids tyrosine and tryptophan at $\sim 1620 \mathrm{~cm}^{-1}$. Mineral to matrix ratios were computed by dividing the $\mathrm{PO}_{4}^{3-} v_{1}$ band area by the matrix band area. To generate false colour mapping plots of dried samples, the mineral to matrix ratio was calculated at each point in the array. These values were then scaled for each map to represent the intensity range of 5-95\% of the maximum signal intensity. A linear interpolation routine was used to smooth the map intensity profile. For mineral to matrix ratio measurements, 80, 53 and 87 Raman spectra from 11, 9, and 13 nodules for ESCs, MSCs and OBs, respectively, (obtained from a minimum of 2 separate cell isolations in the case of MSCs and OBs) were analysed; 44 spectra from 3 native bone samples were also examined.

\section{Gene expression}

At indicated time points, cultures of ESCs, MSCs and OBs were collected, pelleted in microcentrifuge tubes and snap frozen in liquid $\mathrm{N}_{2}$. RNA was extracted using Qiashredder and RNeasy kits (Qiagen, Hilden, Germany). Sensimix OneStep kit (Quantace, London, UK) was used to synthesise cDNA and to amplify cDNA by PCR in a single step, using SYBR green to detect increases in amplicon concentration. Thermal cycling and SYBR green fluorescence detection were performed using a Corbett Rotorgene (Qiagen). All primers were designed using Primer Bank free software (http://pga.mgh.harvard. edu/primerbank/). Sequences and cycling conditions of all primers are listed in Table 1. For comparison of the expression of housekeeping genes (Gapdh, B2m and Actb) equal masses of RNA, isolated from each cell type, were used in all reaction tubes. Expression of a gene of interest in one selected reference sample (one of the ESC samples; $\mathrm{R})$ was compared to the expression of the same gene in a sample of interest (I) by the equation:

$$
R E=E^{-(C t[I]-C t[R])}
$$

where RE is the relative expression of the gene of interest in I compared to R; E is the efficiency of the primer pair;
$\mathrm{Ct}[\mathrm{I}]$ is the PCR cycle number at which the fluorescent signal reaches a given threshold for a sample of interest; and $\mathrm{Ct}[\mathrm{R}]$ is the PCR cycle number at which the fluorescent signal reaches a given threshold for the reference sample. Relative gene expression with respect to cell type or time was measured by the Pfaffl method (Pfaffl, 2001) using the equation:

$$
R E=\frac{E_{G O I}^{-(C t[d x]-C t[d 0])}}{E_{N O R}^{-(C t[d x]-C t[d 0])}}
$$

where RE is the expression of a gene at a timepoint of interest $(d x)$ relative to expression at day $0(\mathrm{~d} 0)$. $\mathrm{E}_{\mathrm{GO}}$ is the efficiency of the primer pair of the gene of interest, $\mathrm{E}_{\mathrm{NOR}}$ is the efficiency of the normalising gene primer pair, and $\mathrm{Ct}[\mathrm{dx}]$ and $\mathrm{Ct}[\mathrm{d} 0]$ are the PCR cycle numbers where the fluorescent signal of either the gene of interest or the normalising gene reaches a given intensity threshold. All PCR reactions were performed in duplicate. Efficiencies of all primer pairs were calculated by serial dilutions of either RNA isolated from ESCs (for Nanog and Oct4) or from OBs (for all other genes).

\section{Statistics}

Statistical analyses of calcium quantification and realtime RT-PCR data were performed using ANOVA with a post-hoc Tukey test. A Kruskal-Wallis non-parametric ANOVA was used to determine significance $(p<0.05)$ between mineral to matrix ratios. A Mann-Whitney test with Bonferroni correction was used to test for statistical significance between individual groups. The slopes and correlation coefficients of linear regressions calculated for Gapdh expression as a function of time in culture were compared by calculating the $t$-statistic and by using Fisher's method, respectively. Replicate numbers are stated for each experiment in the figure legends and in the Results. Significance was noted at $p<0.05$.

\section{Results}

After $21 \mathrm{~d}$, ESCs, OBs and MSCs all formed mineralised nodules that stained positively with the calcium stain ARS. ESC cultures displayed more extensive staining than MSC and OB cultures, however, covering almost the entire culture surface (Fig. 1A-C, respectively). A calcium quantification assay confirmed that ESC cultures accumulated significantly more calcium per well than either MSC or OB after $21 \mathrm{~d}$ (Fig. 1D). We also noticed differences in the staining pattern of ESC nodules as compared to OB and MSC nodules. While nodules formed from all three cell types fluoresced when stained with ARS (Fig. 1E-G), in ESCs the areas stained with ARS had poorly defined boundaries while, in contrast, the boundaries of mineralised nodules formed from both MSCs and OBs were clearly defined, with a sudden decrease in ARS fluorescence intensity at the nodule edges.

To better understand these differences in staining patterns, we examined the live cultures with micro-Raman spectroscopy. Raman spectra collected in a line across a typical live mineralised MSC nodule (Fig. 1H) were notable 

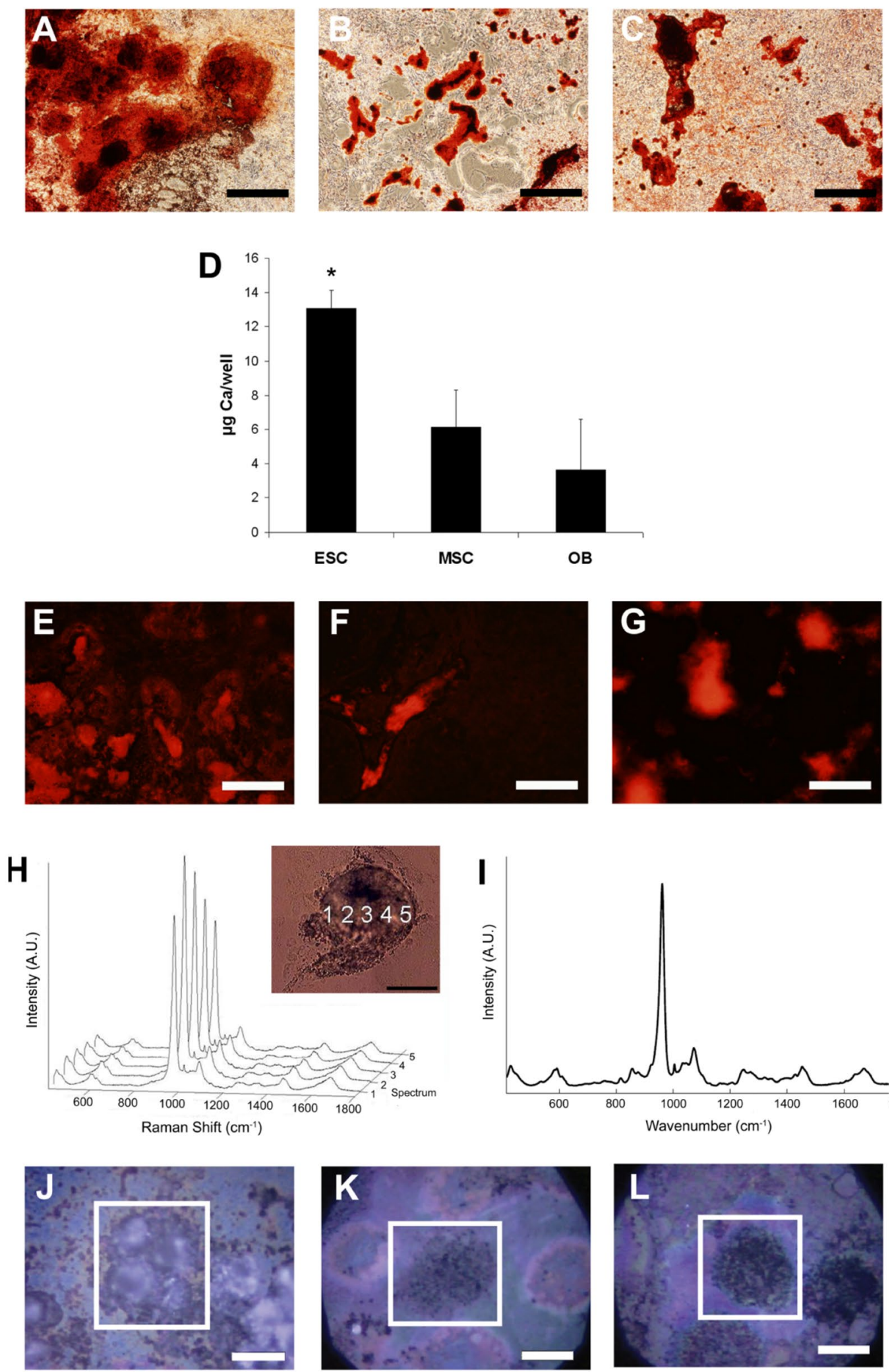

Fig.1. Legend on
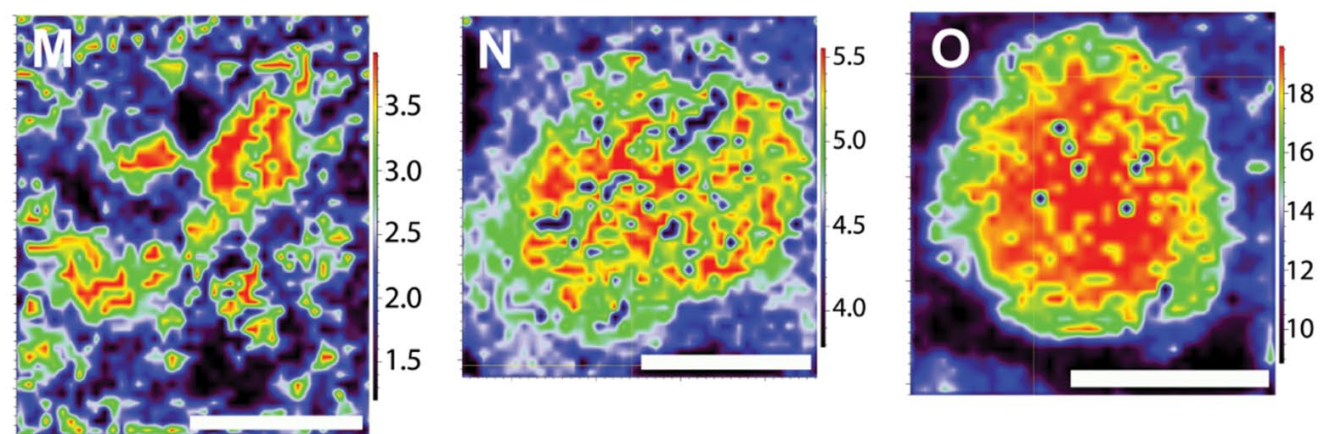
next page 
Fig. 1. (Previous page) Histological staining and spectroscopic analyses of mineralised nodules formed from ESC, MSC and OB. Alizarin Red S (ARS) staining of mineralised nodules formed in cultures of (A) ESC, (B) MSC and (C) OB. Notice the extensive staining in ESC compared to MSC and OB. Scale bar $=500 \mu \mathrm{m}$. (D) Total calcium per well in cultures of ESC, MSC and OB expressed as $\mu \mathrm{g} \mathrm{Ca/well} \mathrm{(means} \pm$ standard deviation) * indicates ESC cultures contained significantly $(p<0.05)$ more Ca per well than either MSC or OB $(n=6)$. Fluorescence micrographs of typical mineralised nodules formed from (E) ESC, (F) MSC and (G) OB stained with ARS. Scale bar $=500 \mu$ m. Note that while $\mathrm{OB}$ and MSC nodules fluoresce in discrete areas, the fluorescence in ESC is more diffuse. (H) Representative Raman spectra of a line scan of a typical live mineralised nodule formed from MSC. Inset shows the position at which each of the spectra was collected. (I) Raman spectrum of a fresh bone sample harvested from an adult mouse. False-colour plots of Raman maps created from spectra of dried mineralised nodules formed from ESC (J,M), MSC (K,N) and OB (L,O) with their respective images of individual nodules. Scale bar in all images is $20 \mu \mathrm{m}$. False colour images were created by collecting Raman spectra then taking the ratio of the $\mathrm{PO}_{4}^{3-} v_{1}$ area to the area of the Amide I peak and scaling each map to represent the intensity range of 5-95\% of the maximum signal intensity. Colours represent the relative amount of mineral at individual points in nodules. Note that ESC nodules lack discrete boundaries.

Fig. 2. Univariate peak analysis of mineral-tomatrix ratios in ESC, MSC and $\mathrm{OB}$ nodules, and native bone. Mineral-to-matrix was calculated by measuring the area of the $\mathrm{PO}_{4}^{3-} v_{1}$ peak divided by the area of the Amide I band. In (A) the data scatter is plotted with dotted lines representing constant mineral to matrix ratios. (B) Mean mineral to matrix ratio ( \pm standard deviation). * represents a statistically significant difference between the given sample and bone. $\dagger$ significantly different from $\mathrm{OB}$; significantly different from MSC. 80, 53 and 87 Raman spectra from 11, 9, and 13 nodules for ESC, MSC and OB, respectively, (obtained from a minimum of 2 separate cell isolations in the case of MSCs and OBs) were analysed; 44 spectra from 3 native bone samples were also examined.
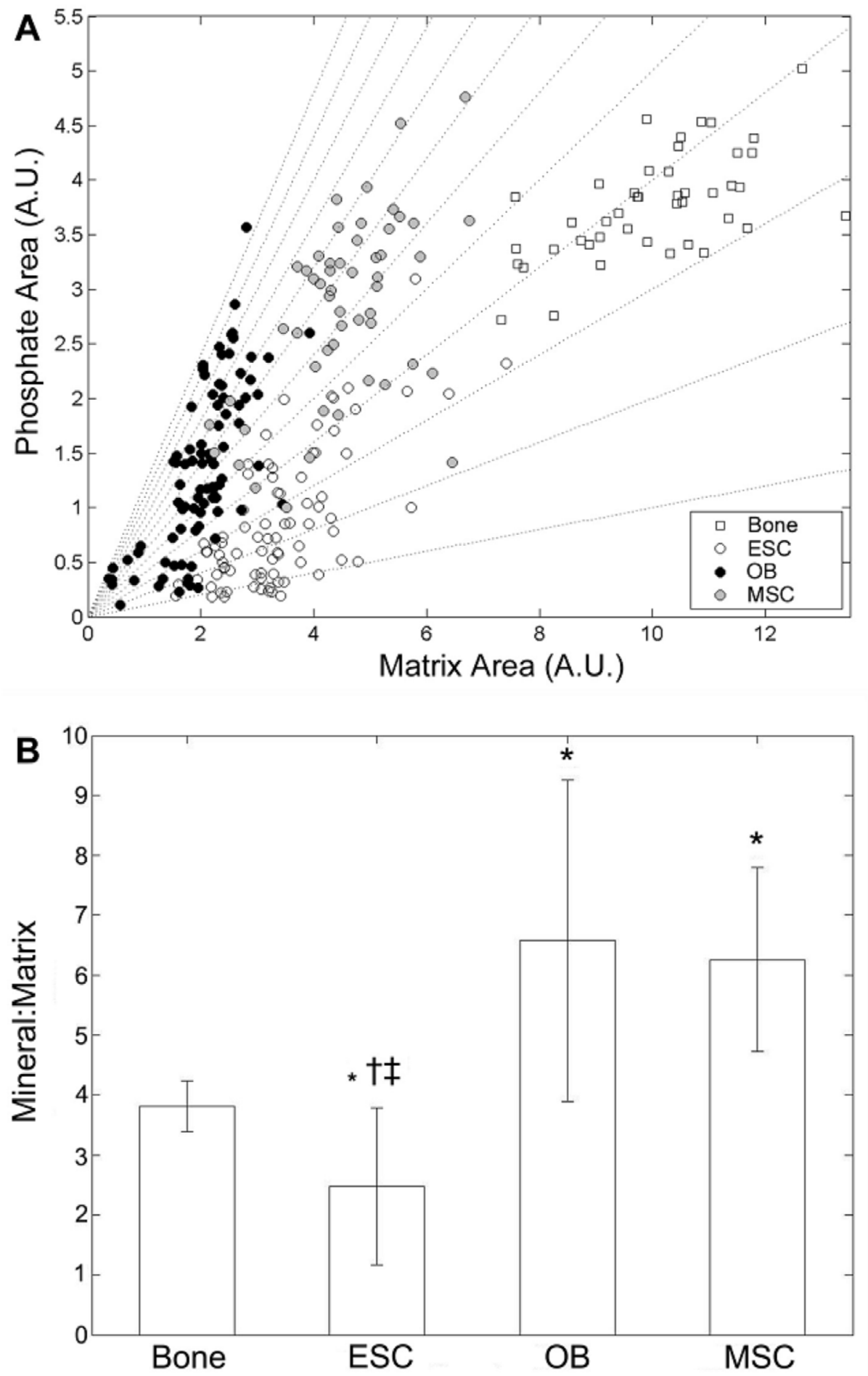

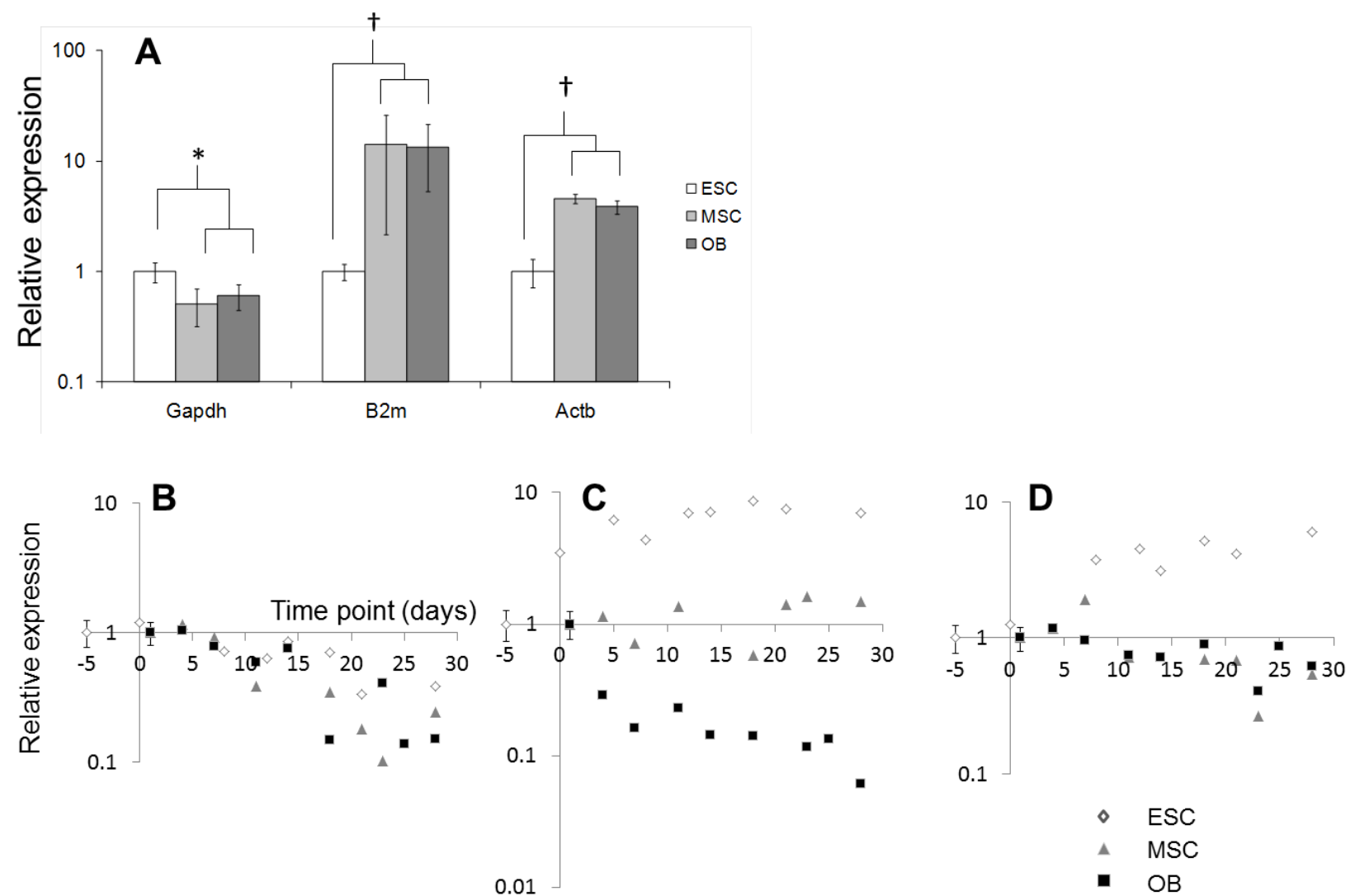

Fig. 3. Comparison of housekeeping gene expression in cultures of ESCs, MSCs and OBs. In undifferentiated cells (A), Gapdh was expressed at levels significantly lower in both MSCs and OBs than in ESCs, while both $B 2 m$ and $A c t b$ were expressed at significantly higher levels in MSCs and OBs than in ESCs (* indicates $p<0.05$, $\dagger$ indicates $p<0.01 ; n=5)$. During a time course of differentiation, Gapdh declined in all cells at a similar rate (B). B2m (C) and $A c t b$ (D) increased markedly in cultures of ESCs over a time period of $28 \mathrm{~d}$. In OBs, Actb declined during the same time period, while $B 2 m$ declined in OBs, but remained constant in MSCs.

for peaks with marked similarities to spectra of native bone (Fig. 1I) including strong peaks near $960 \mathrm{~cm}^{-1}$ (resulting from symmetric stretch of the $\mathrm{PO}_{4}^{3-} v_{1}$ ), $1070 \mathrm{~cm}^{-1}$ (resulting from in-plane vibrations of substituted $\mathrm{CO}_{3}{ }^{2-} v_{1}$ ), and 1,595$1,720 \mathrm{~cm}^{-1}$ and 1,243-1,269 $\mathrm{cm}^{-1}$ (corresponding to Amide I and III). Spectral maps of dried nodules formed from ESC (Fig. 1J and M), MSC (Fig. 1K and N) and OB (Fig. 1L and $\mathrm{O}$ ), which represent the ratio of the mineral content to the protein content in false colour, revealed discrete mineralisation boundaries in $\mathrm{OB}$ and MSC nodules, while ESC nodule boundaries were more diffuse.

In addition to differences in the distribution of mineral in ESCs compared to MSCs or OBs, we also found that the mineral-to-matrix ratio, an average measure of the relative amount of phosphate mineral present in nodules as compared to the amount of protein, was significantly lower in ESC than in either OB, MSC or native bone samples (Fig. 2). We found a broad range of mineral peak areas for given matrix areas (Fig. 2A, which depicts the scatter of the mineral and matrix peak areas for ESC, OB and MSC nodules and native bone), but the trend was for increasing mineral content with increasing matrix content for all samples. ESC had the lowest phosphate peak area among all the groups, which when combined with their intermediate matrix peak area yielded the lowest mineral to matrix ratios (Fig. 2B). Conversely, while OB and MSC nodules had similar matrix levels to ESC, they had higher mineral peak areas, yielding significantly higher mineral to matrix ratios. Bone samples yielded the highest mineral and matrix peak areas and therefore their spectra clustered in the upper right portion of the scatter plot, with a mineral to matrix ratio significantly greater than ESC nodules.

To attempt to explain the differences in ARS uptake and Raman spectra of bone nodules, we next tested for differences in the molecular mechanisms of osteogenic differentiation by comparing and quantifying gene expression in ESCs, MSCs and OBs. To compare gene expression between cell types, the selection of a normalising housekeeper gene that is expressed similarly both in different cell types and under different conditions is critical. We compared three commonly used housekeeping genes: Gapdh (glyceraldehyde-3-phosphate dehydrogenase; an enzyme necessary for glycolysis), $B 2 m$ ( $\beta 2$-microglobulin; a component of the major histocompatibility complex (MHC) present on all nucleated cells) and Actb ( $\beta$-actin; a component of the cytoskeleton) (Fig. 3). At day 0 (i.e. when comparing undifferentiated ESCs, MSCs and OBs) Gapdh expression was significantly lower in both MSCs and OBs than in ESCs $(p<0.05)$, while both $B 2 m$ and $A c t b$ expression was significantly higher $(p<0.01)$ (Fig. 3A). 

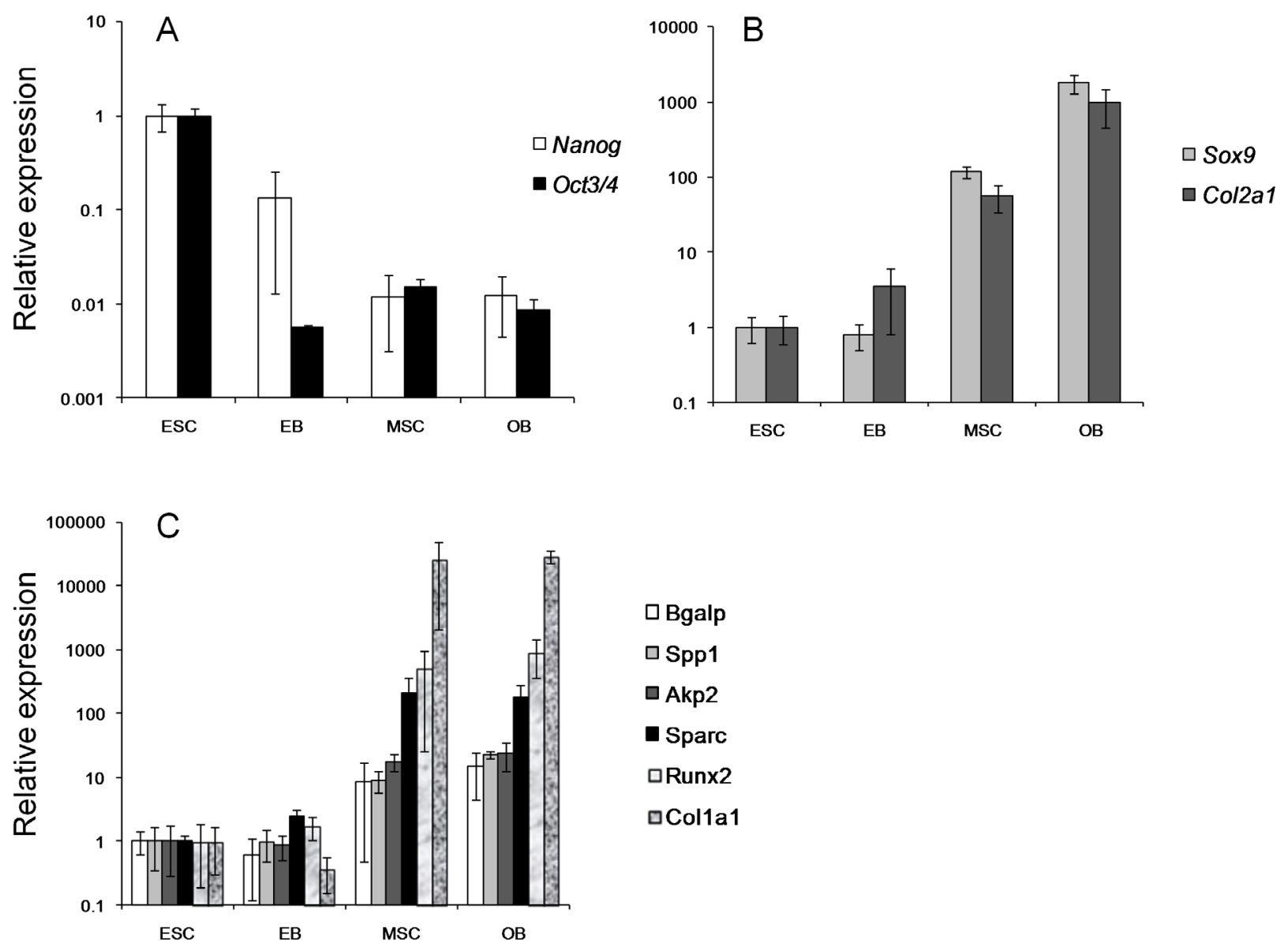

Fig. 4. Relative expression of genes involved in pluripotency, and chondrogenic and osteogenic differentiation in undifferentiated ESCs, EB derived cells, MSCs and OBs. (A) The expression of markers of pluripotency (Nanog, Oct4) was greater in ESCs than in either EB-derived cells (ESCs cultured for $5 \mathrm{~d}$ in suspension in the absence of LIF), MSCs or OBs. (B) The expression of markers of chondrogenic differentiation (Sox9, Col2a1) was $\sim 100$ fold (MSCs) or 1,000 fold (OBs) greater than in ESCs at day 0. (C) Markers of osteogenic differentiation (Bglap 1, Spp1, Akp2, Sparc, Runx2, Colla1) were also expressed at factors of $\sim 10$ to $\sim 10,000$ greater in undifferentiated MSCs or undifferentiated OBs compared to undifferentiated ESCs or EB-derived cells ( $n=3$ or 4 in all groups).

There was no significant difference in the expression of Gapdh when comparing MSCs and OBs with d5 embryoid bodies (corresponding to day 0 in our ESC osteogenic differentiation experiments). During the course of a differentiation experiment we could not detect differences in the expression of Gapdh between ESCs, MSCs and OBs, with no significant differences in either the slopes of linear regressions ( $p>0.1$ for all comparisons) calculated for the expression data as a function of time in culture, or their correlation coefficients $(p>0.5)$ (Fig. 3B). This was also true when Gapdh expression was normalised to that in EBs (day 0 in ESC osteogenic differentiation experiments). In contrast, both $B 2 m$ and $A c t b$ increased in ESCs over the course of the differentiation experiment by factors of 6-10 fold, while declining or remaining unchanged in both MSCs and OBs (Fig. 3C and 3D). As Gapdh expression did not differ between cell types during osteogenic culture, we chose this gene as a normaliser to compare genes of interest between cell types.

We next investigated compared the expression of genes expected to change during osteogenic culture in the three cell types (Nanog, Oct4, Sox9, Col2a1, Bglap, Sparc, Akp2, Spp 1, Runx 2 and Colla1), by comparing expression in undifferentiated ESCs, cells derived from day 5 EBs (corresponding to 'day 0' in our differentiation experiments for ESCs), undifferentiated MSCs, and undifferentiated OBs. In all cases Gapdh was chosen as the normalising gene due to the results described above. As might be expected, at baseline time-points (day 5 [undifferentiated cells] or day 0 [embryoid bodies] in ESCs or at day 1 in MSCs or OBs), markers of osteogenic and chondrogenic differentiation were substantially and significantly greater in MSCs and OBs than in ESCs (Sox9, Col2a1, Bgalp1, Spp1, Akp2, Sparc, Runx2, Colla1), while the opposite was true of genes such as Nanog and Oct4 (Fig. 4). We obtained similar results by normalising gene expression to the amount of input RNA in our PCR reactions (data not shown). All genes remained detectable in all cell types.

Having established baseline comparisons of gene expression between undifferentiated cell types, we next investigated the expression of selected chondrogenic and osteogenic genes during the osteogenic culture of ESCs, 

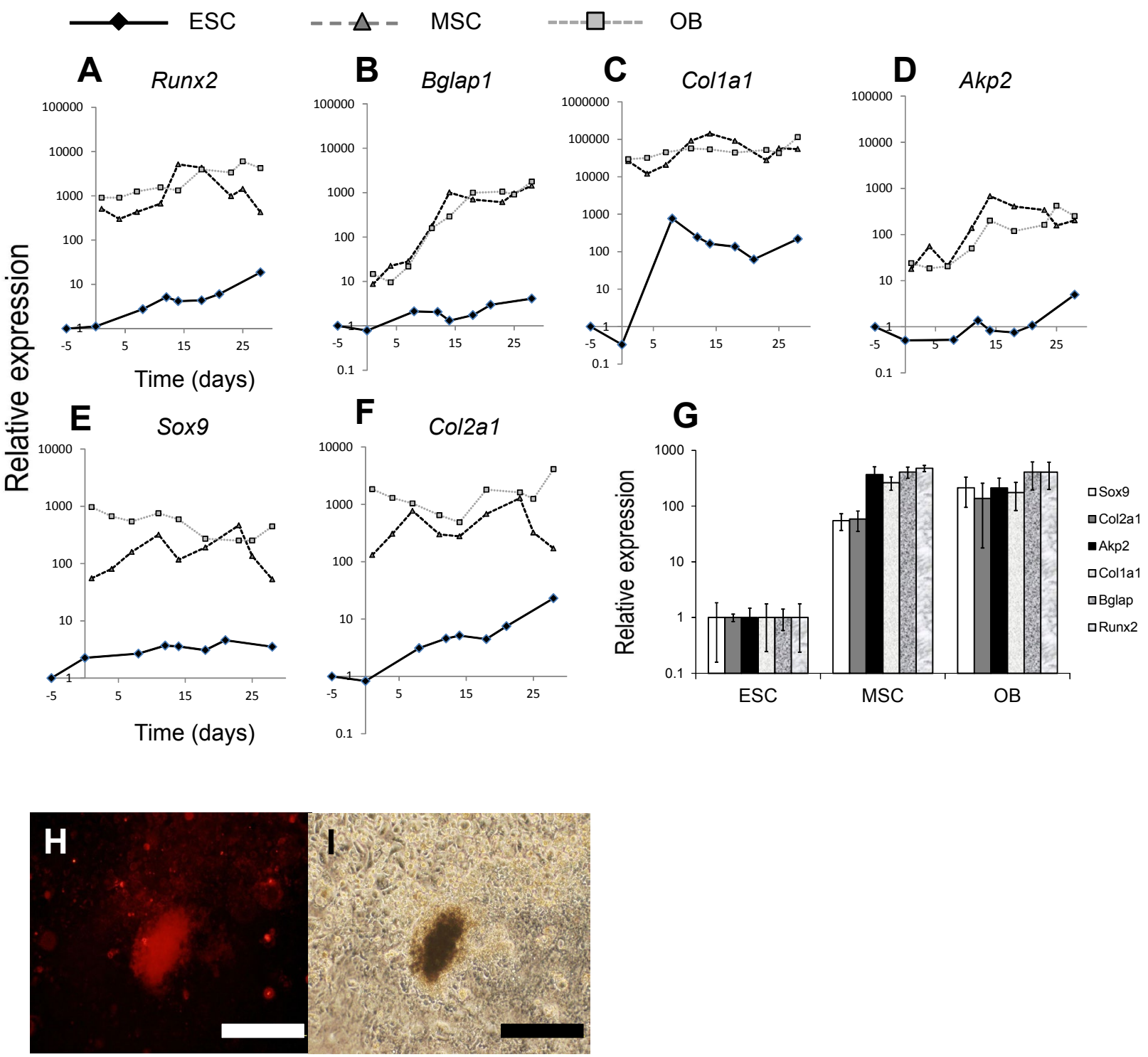

Fig. 5. Time course expression of osteogenic (A-D) or chondrogenic ( $\mathbf{E}$ and $\mathbf{F})$ genes in cultures of ESCs, MSCs or OBs, respectively, and peak expression comparison of genes $(\mathbf{G})$. For each gene, values are given as the relative expression levels for each of the three cell types at baseline time-points (i.e. in undifferentiated cells - day 1 in MSCs and OBs and day 5 in ESCs), thus charts A-F compare the expression of each gene between cell types. Time course plots are from a single differentiation experiment and are representative of data from two separate cell isolations. $\mathbf{G}$ compares the peak expression of selected genes normalised to ESCs (by taking the means of the three highest data points in each time-course) illustrating a significantly lower expression in ESCs - by factors of $\sim 100$ to $\sim 1,000-$ of all genes compared to either MSCs or OBs (results shown as \pm standard deviation; $n=3$ ). Ethidium homodimer-1 staining of the ESC nodule demonstrates evidence of cell death in the nodule $(\mathbf{H})$ (a phase contrast image of the nodule is provided in I). Scale bars indicate $200 \mu \mathrm{m}$.

OBs and MSCs. To directly and quantitatively compare gene expression between cell types during the time-course of differentiation, we normalised expression to the baseline comparisons obtained in our experiments above. Fig. 5 shows that during osteogenic culture of all cell types, expression of osteogenic and chondrogenic genes was always greater in both MSCs and OBs relative to ESCs (despite the comparative amounts of mineral that formed in ESCs, MSCs and OBs, as shown in Fig. 1). Runx2 and Bglap expression increased modestly in ESCs during osteogenic differentiation (by factors of $\sim 5-10$; Fig. 5A and B) but remained between 100-1000 lower than in MSCs or
OBs even at peak expression levels (Fig. 5G). In addition, Bglapl expression increased in both MSCs and OBs by a factor of $\sim 100$ during a time-course of differentiation, while increasing by a factor of only $\sim 4$ in ESCs. The expression of type I collagen increased by $~ 100-1000$ times in ESCs during a time course of differentiation, while remaining relatively unchanged in MSCs and OBs (Fig. 5C). But due to the significantly higher baseline expression of this gene in the latter cell types, Collal was expressed $\sim 100-1000$ times lower in ESCs than MSCs or OBs at peak expression levels (Fig. 5G). Akp2 expression increased by a factor of $\sim 10$ in MSCs and OBs while remaining relatively 
unchanged in ESCs (Fig. 5D), with a peak expression $\sim 100$ times greater in MSCs or OBs than in ESCs. Similar to osteogenic genes, the expression of chondrogenic genes Sox9 and Col2al increased modestly in ESCs during differentiation, while fluctuating or showing biphasic patterns of expression in either MSCs or OBs (Fig. 5E and F). Again, due to significantly higher baseline expression of $\operatorname{Sox} 9$ and Col2al in the latter cell types, peak expression of these genes remained $\sim 100$ higher than in ESCs (Fig. $5 \mathrm{G})$.

We also noticed that mineralised nodules formed in ESC cultures were markedly different in appearance by light microscopy compared to either MSC or OB nodules, with a darker, thicker appearance that prevented light transmission (see Gentleman et al., 2009). To explore the possibility that cell death and the necrotic accumulation of insoluble $\mathrm{Ca}^{2+}$ salts might explain the accumulation of mineralised ARS-positive tissue in ESC cultures, we used ethidium homodimer-1 to stain for dead cells within ESC nodules. Fig. $5 \mathrm{H}$ and I show that cell death is evident in ESC nodules.

\section{Discussion}

Stem cells, such as ESCs and MSCs, are considered as potential sources of cells for use in regenerative medicine and tissue engineering strategies for the skeleton. Before they can be used for these purposes, however, it is necessary to demonstrate that they are able to function in the same way as the cells and tissues they are intended to replace. Here, we investigated the morphology and biochemical composition of nodules formed by ESCs and MSCs, and compared them to those formed by primary osteoblasts. We then qualitatively related this to the quantity of mineral formed by each cell type and the magnitude of the expression of genes involved in osteogenic differentiation.

As in previous publications, we found that ESCs, MSCs and OBs form ARS-positive mineralised areas after prolonged culture in media containing osteogenic supplements (Buttery et al., 2001; Karp et al., 2006; Sottile et al., 2003; zur Nieden et al., 2003; zur Nieden et al., 2005). Similarly, in agreement with a previous study, we found that whole ESC cultures accumulate more calciumcontaining mineral than OB or MSC (Shimko et al., 2004). But we also observed that the morphology of mineralised nodules was subtly different in ESC cultures compared to OB and MSC cultures, and that both the ratio of mineralto-matrix and the absolute phosphate concentration in individual ESCs nodules was lower compared to nodules in MSCs, OBs or in native bone. This indicates a more diffuse but more extensive mineral accumulation in ESC cultures, and suggests that a different mechanism may mediate calcium deposition in the former cultures as compared to the latter. Therefore, we next thoroughly investigated the gene transcription profiles of ESCs, MSCs and OB cultures over the differentiation period, comparing expression of both osteogenic and chondrogenic genes. We found that many genes involved in osteogenic and chondrogenic differentiation were expressed at levels several orders of magnitude lower in ESCs than in MSCs or OBs, despite the high levels of mineralisation in the former cell cultures.

To allow us to compare gene expression between the three cell types, we first had to validate a suitable housekeeping gene to act as normaliser, and chose to investigate three commonly used housekeeping genes. In all cases, we observed no difference in any housekeeping gene when comparing MSCs with OBs. This is perhaps due to their similar morphology and shared cell lineage. In contrast there were significant differences in the expression of all housekeeping genes when comparing undifferentiated ESCs to either MSCs or OBs. Gapdh, for instance, was expressed at slightly higher levels in undifferentiated ESCs than in either undifferentiated MSCs or OBs, but was not significantly different after EB formation ( $5 \mathrm{~d}$ post differentiation, and referred to as day 0 in our differentiation experiments). This is probably because cells of the early embryo, including embryonic stem cells, have fewer mitochondria than more differentiated cells (Facucho-Oliveira and St John, 2009) and rely to a greater extent on glycolysis rather than aerobic respiration for ATP generation (Cho et al., 2006; Facucho-Oliveira et al., 2007; Powers et al., 2008; St John et al., 2005). B2m and Actb, on the other hand were expressed at higher levels in MSCs and OBs compared to ESC, supporting previous observations where Tian et al. (1997) were unable to detect MHC class I molecules in ESCs by FACS, and Dressel et al. (2009) also noted low $B 2 m$ in ESC lines. The low expression of the cytoskeletal $\beta$-actin gene in ESCs compared to MSCs or OBs may reflect the fact that ESCs have a poorly defined cytoskeleton, and grow as rounded colonies rather than flat, spread cells (as is the case in MSCs and OBs).

During differentiation, expression of Gapdh declined in all cell types at similar rates, with no significant difference in expression between the three cell types, a fact that allowed us to use this housekeeping gene as a normaliser between cell types. The decline we observed, however, may reflect the increase in mitochondria and decreased reliance on glycolysis that accompanies ESC differentiation, and also with the observation that during the course of osteogenic differentiation, osteoblasts also decrease their reliance on glycolysis and increase their reliance on oxidative metabolism (Komarova et al., 2000). The variations in the expression of housekeeping genes between cell types and during differentiation illustrates that careful validation of housekeeping gene expression should be performed before choosing normalisers to analyse gene expression in such experiments.

During osteogenic culture of both OBs and MSCs, the substantial upregulation of Bglap1, the gene for osteocalcin, and $A k p 2$, the gene for tissue nonspecific alkaline phosphatase (TNAP), with more subtle increases in Runx2 and Colla1, reflect the differentiation of osteogenic cells, and accompany the formation of bone matrix and the deposition of mineral in vitro (Aubin et al., 1995). Accordingly, we concurrently observed formation of raised, ARS-positive nodules in culture, which we have previously shown to exhibit characteristics similar to those of native bone tissue. In ESCs, however, there were only modest increases in Bglap, Akp2 and Runx2, and when peak expression of these genes in ESCs was compared with peak expression in MSCs and OBs, we 
found that all osteogenic genes were expressed at factors of 200-500 higher in the latter cells. This would seem to indicate that osteogenesis is less efficient in ESCs than in MSCs or OBs under the conditions studied. Considering that ESCs, as uncommitted cells, may undergo nonspecific differentiation to other lineages in parallel with osteogenic differentiation, which is less true of MSCs or OBs, this finding alone is not surprising. But coupled with the observation that mineralisation, measured by ARS uptake, was higher in ESCs than in the other cell types, our results seem paradoxical. We therefore think it likely that much of the calcium ion accumulation, measured by ARS staining (which detects only the presence of $\mathrm{Ca}^{2+}$ bound to inorganic anion and therefore does not specifically detect bone-specific mineralisation), that occurs in differentiating ESCs in these conditions is not osteoblast-dependent. One possible mechanism for this is that mineral deposition may be promoted by other isoforms and/or homologues of alkaline phosphatase - undifferentiated ESCs have a high level of alkaline phosphatase activity. In previous experiments, however, we found that alkaline phosphatase activity (measured biochemically) was no greater in ESCs than in MSCs or OBs (Gentleman et al., 2009). A more likely explanation is that dystrophic calcification may occur in necrotic cells in culture. Necrotic tissue is known to promote inappropriate mineralisation both in vivo and in vitro due to the accumulation of insoluble salts containing calcium and phosphate (Gadeau et al., 2001; Hussmann et al., 1995; Zhao et al., 2009), and we observed cell death in ESC nodules by ethidium homodimer-1 uptake (Fig. $5 \mathrm{H}$ and I). ESC nodules are thick multi-layered structures, and it is possible that nutrient depletion at the centre of such structures led to necrosis. We did not observe significant ARS staining of ESC cultures in the absence of $\beta$-glycerophosphate (not shown), indicating that the presence of phosphate was necessary for the dystrophic mineralisation we observed. In addition, mice that lack TNAP have a defect in bone mineralisation (Narisawa et al., 1997) and osteoblasts from these mice form bone nodules that do not mineralise in culture (Wennberg et $a l ., 2000)$. In our studies, the gene for this enzyme (Akp2) was expressed at a factor of 100 times lower in ESCs than in MSCs or OBs, indicating again that mineralisation is probably nonspecific. It would be interesting to examine the osteogenic differentiation of ESCs obtained from such knockout mice (in comparison with wild-type ESCs) to determine if non-specific mineralisation is responsible for the calcium deposition observed in our study.

That Sox9 and Col2al were expressed at higher levels in OBs compared to MSCs was surprising. During the normal course of development, the parietal and frontal skull bones of mice (from which OBs are derived) form by intramembranous ossification, with no cartilage intermediate. However, this process has been shown to be perturbed by mechanical force (Shapiro, 2008), growth factor exposure (Govindarajan and Overbeek, 2006) and tissue location (Leucht et al., 2008) and thus we suggest that the chemical milieu of the cell culture environment may promote chondrogenic gene expression in OBs. This is supported by our previous observations of localisation of collagen type II by immunostaining and Raman spectroscopy in both OB and MSC (Gentleman et al., 2009). The rise in Col2al gene expression that accompanied osteogenic differentiation in MSCs suggests (but does not prove) that, at least in part, osteogenic differentiation proceeds via a cartilage intermediary.

Our results certainly do not exclude the possibility that it is possible to produce osteogenic cells from embryonic stem cells for tissue engineering applications with greater efficiency. While most of the published papers on osteogenic differentiation describe using only osteogenic supplements such as $\beta$-glycerophosphate, ascorbate, dexamethasone (Buttery et al., 2001; Karp et al., 2006; Sottile et al., 2003), BMPs (zur Nieden et al., 2005), and vitamin D (zur Nieden et al., 2003) to promote osteogenesis, Kawaguchi et al. (2005) did not observe induction of osteogenesis without stimulation of EBs with retinoic acid (others have also noted increased osteogenesis by adding this molecule (Phillips et al., 2001; Yamashita et al., 2005; zur Nieden et al., 2007)). Notably, in this study the authors observed upregulation of Bgalp by a factor of $\sim 100$, which indicates a much greater efficiency of osteogenic differentiation than in our study, where maximal increases in the expression of this gene were only $\sim 4$ times greater than baseline. Here the authors suggest that early exposure to retinoic acid promotes either the differentiation of neural crest (which gives rise to the bones of the skull) or redirects paraxial mesoderm to form mesenchymal tissues. Further studies may seek to address the poorly-understood mechanisms of osteogenesis by examining the osteogenic potential of subsets of cells that arise in differentiating ESC cultures, and the effect of molecules such as retinoic acid in modulating this process.

Other recent studies have described protocols for deriving and selecting cells with properties of MSCs from cultures of differentiating ESCs (Gruenloh et al., 2011; Lai et al., 2011; Olivier et al., 2006). Our studies do not shed light on how early ESC commitment to cells of the skeletal or mesenchymal lineage occurs. We did not test whether ESC-derived MSC-like cells expressed osteogenic genes at similar levels to either adult-derived MSCs or OBs, but we suggest that future experiments on ESC-derived osteogenic cells should be compared directly with control, adult cells of known osteogenic potential. To our knowledge, there have been no demonstrations to date that ESC-derived osteogenic cells contribute to new, functional bone tissue in an animal model of fracture healing, a necessary test before ESC-derived osteoblasts can be used as a therapy in humans, and safety concerns over the potential of ESCs to cause teratomas will have to be overcome before these cells can be considered for therapeutic use.

We conclude that mineralisation of ESCs cultured under conditions commonly used to promote osteogenic differentiation occurs without either the characteristic high expression or upregulation of genes observed in MSCs and OBs, suggesting a non-specific accumulation of mineral in ESC cultures. 


\section{Acknowledgements}

The authors would like to thank the EPSRC for funding. N.D.E. gratefully acknowledges the Medical Research Council, UK for fellowship funding. R.J.S. gratefully acknowledges funding from the Rothermere Foundation, the National Science and Engineering Research Council Canada and the Canadian Centennial Scholarship Fund. The funders had no role in study design, data collection and analysis, decision to publish, or preparation of the manuscript. We wish to confirm that there are no known conflicts of interest associated with this publication and there has been no significant financial support for this work that could have influenced its outcome.

\section{References}

Arrington ED, Smith WJ, Chambers HG, Bucknell AL, Davino NA (1996) Complications of iliac crest bone graft harvesting. Clin Orthop Relat Res 329: 300-309.

Aubin JE, Liu F, Malaval L, Gupta AK (1995) Osteoblast and chondroblast differentiation. Bone 17: 77S-83S.

Bielby RC, Boccaccini AR, Polak JM, Buttery LD (2004) In vitro differentiation and in vivo mineralization of osteogenic cells derived from human embryonic stem cells. Tissue Eng 10: 1518-1525.

Boraiah S, Paul O, Hawkes D, Wickham M, Lorich DG (2009) Complications of recombinant human BMP-2 for treating complex tibial plateau fractures: a preliminary report. Clin Orthop Relat Res 467: 3257-3262.

Bruder SP, Kurth AA, Shea M, Hayes WC, Jaiswal N, Kadiyala S (1998) Bone regeneration by implantation of purified, culture-expanded human mesenchymal stem cells. J Orthop Res 16: 155-162.

Buttery LD, Bourne S, Xynos JD, Wood H, Hughes FJ, Hughes SP, Episkopou V, Polak JM (2001) Differentiation of osteoblasts and in vitro bone formation from murine embryonic stem cells. Tissue Eng 7: 89-99.

Cho YM, Kwon S, Pak YK, Seol HW, Choi YM, Park do J, Park KS, Lee HK (2006) Dynamic changes in mitochondrial biogenesis and antioxidant enzymes during the spontaneous differentiation of human embryonic stem cells. Biochem Biophys Res Commun 348: 1472-1478.

Dressel R, Guan K, Nolte J, Elsner L, Monecke S, Nayernia K, Hasenfuss G, Engel W (2009) Multipotent adult germ-line stem cells, like other pluripotent stem cells, can be killed by cytotoxic T lymphocytes despite low expression of major histocompatibility complex class I molecules. Biol Direct 4: 31 .

Evans MJ, Kaufman MH (1981) Establishment in culture of pluripotential cells from mouse embryos. Nature 292: 154-156.

Facucho-Oliveira JM, St John JC (2009) The relationship between pluripotency and mitochondrial DNA proliferation during early embryo development and embryonic stem cell differentiation. Stem Cell Rev 5: 140158.

Facucho-Oliveira JM, Alderson J, Spikings EC, Egginton S, St John JC (2007) Mitochondrial DNA replication during differentiation of murine embryonic stem cells. J Cell Sci 120: 4025-4034.

Friedenstein AJ, Chailakhjan RK, Lalykina KS (1970) The development of fibroblast colonies in monolayer cultures of guinea-pig bone marrow and spleen cells. Cell Tissue Kinet 3: 393-403.

Gadeau AP, Chaulet H, Daret D, Kockx M, DanielLamaziere JM, Desgranges C (2001) Time course of osteopontin, osteocalcin, and osteonectin accumulation and calcification after acute vessel wall injury. J Histochem Cytochem 49: 79-86.

Gentleman E, Swain RJ, Evans ND, Boonrungsiman S, Jell G, Ball MD, Shean TA, Oyen ML, Porter A, Stevens MM (2009) Comparative materials differences revealed in engineered bone as a function of cell-specific differentiation. Nat Mater 8: 763-770.

Giannoudis PV, Dinopoulos H, Tsiridis E (2005) Bone substitutes: an update. Injury 36 Suppl 3: S20-27.

Giannoudis PV, Einhorn TA, Marsh D (2007) Fracture healing: The diamond concept. Injury 38 Suppl 4: S3-6.

Govindarajan V, Overbeek PA (2006) FGF9 can induce endochondral ossification in cranial mesenchyme. BMC Dev Biol 6: 7.

Gruenloh W, Kambal A, Sondergaard C, McGee J, Nacey C, Kalomoiris S, Pepper K, Olson S, Fierro F, Nolta JA (2011) Characterization and in vivo testing of mesenchymal stem cells derived from human embryonic stem cells. Tissue Eng Part A 17: 1517-1525.

Hussmann J, Russell RC, Kucan JO, Khardori R, Steinau HU (1995) Soft-tissue calcifications: differential diagnosis and therapeutic approaches. Ann Plast Surg 34: 138-147.

Kainer MA, Linden JV, Whaley DN, Holmes HT, Jarvis WR, Jernigan DB, Archibald LK (2004) Clostridium infections associated with musculoskeletal-tissue allografts. N Engl J Med 350: 2564-2571.

Karp JM, Ferreira LS, Khademhosseini A, Kwon AH, Yeh J, Langer RS (2006) Cultivation of human embryonic stem cells without the embryoid body step enhances osteogenesis in vitro. Stem Cells 24: 835-843.

Kawaguchi J, Mee PJ, Smith AG (2005) Osteogenic and chondrogenic differentiation of embryonic stem cells in response to specific growth factors. Bone 36: 758-769.

Komarova SV, Ataullakhanov FI, Globus RK (2000) Bioenergetics and mitochondrial transmembrane potential during differentiation of cultured osteoblasts. Am J Physiol Cell Physiol 279: C1220-1229.

Lai RC, Choo A, Lim SK (2011) Derivation and characterization of human esc derived mesenchymal stem cells. Methods Mol Biol 698: 141-150.

Leucht P, Kim JB, Amasha R, James AW, Girod S, Helms JA (2008) Embryonic origin and Hox status determine progenitor cell fate during adult bone regeneration. Development 135: 2845-2854.

Lieber CA, Mahadevan-Jansen A (2003) Automated method for subtraction of fluorescence from biological Raman spectra. Appl Spectrosc 57: 1363-1367.

McCullen SD, Zhan J, Onorato ML, Bernacki SH, Loboa EG (2010) Effect of varied ionic calcium on human adipose-derived stem cell mineralization. Tissue Eng Part A 16: 1971-1981. 
Narisawa S, Fröhlander N, Millán JL (1997) Inactivation of two mouse alkaline phosphatase genes and establishment of a model of infantile hypophosphatasia. Dev Dyn 208: 432-446.

Olivier EN, Rybicki AC, Bouhassira EE (2006) Differentiation of human embryonic stem cells into bipotent mesenchymal stem cells. Stem Cells 24:19141922.

Pfaffl MW (2001) A new mathematical model for relative quantification in real-time RT-PCR. Nucleic Acids Res 29: e45.

Phillips BW, Belmonte N, Vernochet C, Ailhaud G, Dani C (2001) Compactin enhances osteogenesis in murine embryonic stem cells. Biochem Biophys Res Commun 284: 478-484.

Place ES, Evans ND, Stevens MM (2009) Complexity in biomaterials for tissue engineering. Nat Mater 8: 457 470.

Powers DE, Millman JR, Huang RB, Colton CK (2008) Effects of oxygen on mouse embryonic stem cell growth, phenotype retention, and cellular energetics. Biotechnol Bioeng 101: 241-254.

Savitzky A, Golay MJ (1964) Smoothing and differentiation of data by simplified least squares procedures. Anal Chem 36: 1627-1639

Shapiro F (2008) Bone development and its relation to fracture repair. The role of mesenchymal osteoblasts and surface osteoblasts. Eur Cell Mater 15: 53-76.

Shimko DA, Burks CA, Dee KC, Nauman EA (2004) Comparison of in vitro mineralization by murine embryonic and adult stem cells cultured in an osteogenic medium. Tissue Eng 10: 1386-1398.

Sottile V, Thomson A, McWhir J (2003) In vitro osteogenic differentiation of human ES cells. Cloning Stem Cells 5: 149-155.

St John JC, Ramalho-Santos J, Gray HL, Petrosko P, Rawe VY, Navara CS, Simerly CR, Schatten GP (2005) The expression of mitochondrial DNA transcription factors during early cardiomyocyte in vitro differentiation from human embryonic stem cells. Cloning Stem Cells 7: 141153.
Takahashi K, Yamanaka S (2006) Induction of pluripotent stem cells from mouse embryonic and adult fibroblast cultures by defined factors. Cell 126: 663-676.

Thomson JA, Itskovitz-Eldor J, Shapiro SS, Waknitz MA, Swiergiel JJ, Marshall VS, Jones JM (1998) Embryonic stem cell lines derived from human blastocysts. Science 282: 1145-1147.

Tian L, Catt JW, O’Neill C, King NJ (1997) Expression of immunoglobulin superfamily cell adhesion molecules on murine embryonic stem cells. Biol Reprod 57: 561-568.

Vandesompele J, De Preter K, Pattyn F, Poppe B, Van Roy N, De Paepe A, Speleman F (2002) Accurate normalization of real-time quantitative RT-PCR data by geometric averaging of multiple internal control genes. Genome Biol 3: research0034.

Wennberg C, Hessle L, Lundberg P, Mauro S, Narisawa S, Lerner UH, Millán JL (2000) Functional characterization of osteoblasts and osteoclasts from alkaline phosphatase knockout mice. Bone Miner Res 15: 1879-1888.

Yamashita A, Takada T, Narita J, Yamamoto G, Torii R (2005) Osteoblastic differentiation of monkey embryonic stem cells in vitro. Cloning Stem Cells 7: 232-237.

Zhao Y, Urganus AL, Spevak L, Shrestha S, Doty SB, Boskey AL, Pachman LM (2009) Characterization of dystrophic calcification induced in mice by cardiotoxin. Calcif Tissue Int 85: 267-275.

zur Nieden NI, Kempka G, Ahr HJ (2003) In vitro differentiation of embryonic stem cells into mineralized osteoblasts. Differentiation 71: 18-27.

zur Nieden NI, Kempka G, Rancourt DE, Ahr HJ (2005) Induction of chondro-, osteo- and adipogenesis in embryonic stem cells by bone morphogenetic protein-2: effect of cofactors on differentiating lineages. BMC Dev Biol 5: 1.

zur Nieden NI, Price FD, Davis LA, Everitt RE, Rancourt DE (2007) Gene profiling on mixed embryonic stem cell populations reveals a biphasic role for betacatenin in osteogenic differentiation. Mol Endocrinol 21: 674-685. 